\title{
Environmental Restoration Program waste minimization and pollution prevention self-assessment
}

Oct 1994

Oak Ridge National Lab., TN (United States)

Reproduced and Distributed by:

U.S. DEPARTMENT OF ENERGY

Office of Scientific and Technical Information

P.O. Box 62

Oak Ridge, TN 37831 


\section{DISCLAIMER}

Portions of this document may be illegible in electronic image products. Images are produced from the best available original document. 


\section{DISCLAIMER}

This report was prepared as an account of work sponsored by an agency of the United States Government. Neither the United States Government nor any agency thereof, nor any of their employees, makes any warranty, express or implied, or assumes any legal liability or responsibility for the accuracy, completeness, or usefulness of any information, apparatus, product, or process disclosed, or represents that its use would not infringe privately owned rights. Reference herein to any specific commercial product, process, or service by trade name, trademark, manufacturer, or otherwise does not necessarily constitute or imply its endorsement, recommendation, or favoring by the United States Government or any agency thereof. The views and opinions of authors expressed herein do not necessarily state or reflect those of the Unitod States Government or any agency thereof.
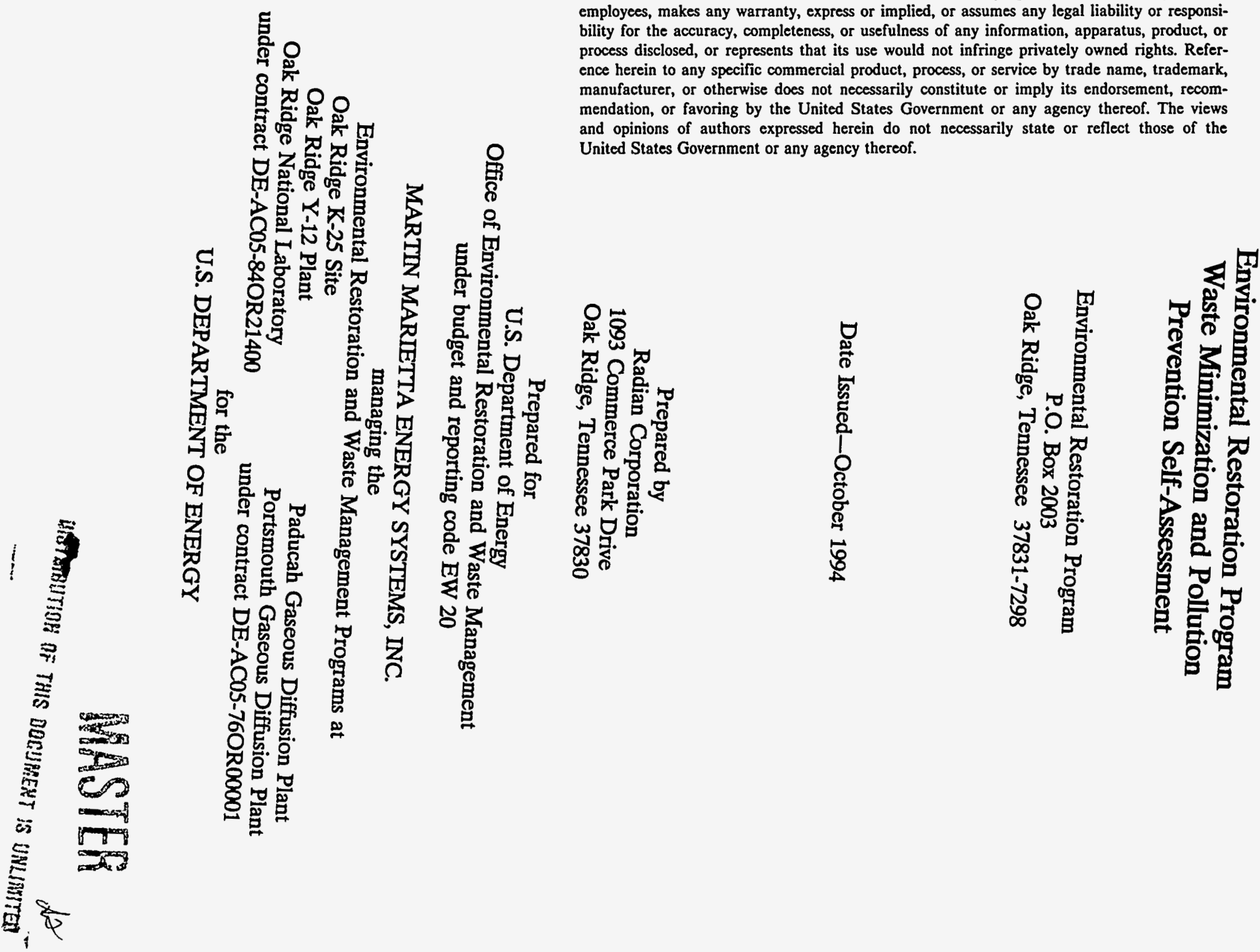


\section{CONTENTS}

TABLES $\ldots \ldots \ldots \ldots \ldots \ldots \ldots \ldots \ldots \ldots \ldots \ldots \ldots \ldots \ldots \ldots$

ACRONYMS $\ldots \ldots \ldots \ldots \ldots \ldots \ldots \ldots \ldots \ldots \ldots \ldots \ldots \ldots \ldots \ldots \ldots$

EXECUTIVE SUMMARY $\ldots \ldots \ldots \ldots \ldots \ldots \ldots \ldots \ldots \ldots \ldots \ldots \ldots$ ix

1. INTRODUCTION $\ldots \ldots \ldots \ldots \ldots \ldots \ldots \ldots \ldots \ldots \ldots \ldots \ldots \ldots \ldots$

2. METHODOLOGY $\ldots \ldots \ldots \ldots \ldots \ldots \ldots \ldots \ldots \ldots \ldots \ldots \ldots \ldots \ldots \ldots$

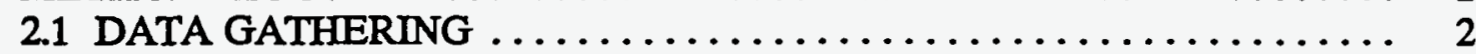

2.2 EVALUATION PROTOCOL ..................... 2

3. RESULTS $\ldots \ldots \ldots \ldots \ldots \ldots \ldots \ldots \ldots \ldots \ldots \ldots \ldots \ldots \ldots \ldots \ldots$

3.1 PROGRAM MANAGEMENT AND INFRASTRUCTURE ........ 3

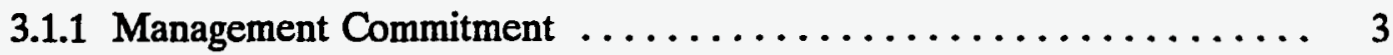

3.1.2 Employee Involvement $\ldots \ldots \ldots \ldots \ldots \ldots \ldots \ldots \ldots \ldots \ldots \ldots \ldots$

3.2 PROGRAM IMPLEMENTATION $\ldots \ldots \ldots \ldots \ldots \ldots \ldots \ldots \ldots \ldots \ldots$

3.2.1 Baseline Data Collection ....................... 10

3.2.2 Data Evaluation and Option Assessment ................ 11

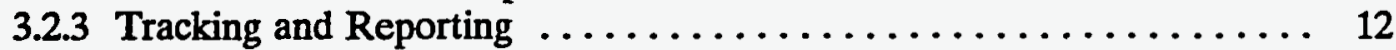

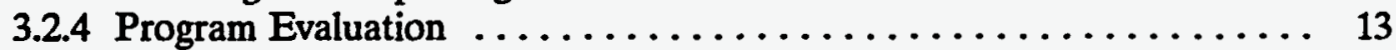

3.3 CONSISTENCY WITHIN THE PROGRAM $\ldots \ldots \ldots \ldots \ldots \ldots \ldots \ldots \ldots$

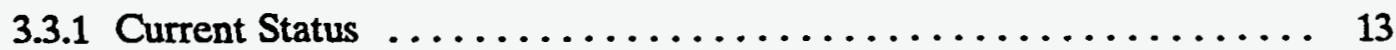

3.3.2 Areas for Waste Minimization and Pollution

Prevention Program Improvement . . . . . . . . . . . . 15

3.4 INTEGRATION WITH THE SITE PROGRAM $\ldots \ldots \ldots \ldots \ldots \ldots \ldots \ldots . \ldots$

3.5 EVALUATION OF VOLUME AND COST REDUCTIONS ......... 16

4. CONCLUSION $\ldots \ldots \ldots \ldots \ldots \ldots \ldots \ldots \ldots \ldots \ldots \ldots \ldots \ldots \ldots \ldots \ldots \ldots$

5. REFERENCES $\ldots \ldots \ldots \ldots \ldots \ldots \ldots \ldots \ldots \ldots \ldots \ldots \ldots \ldots \ldots \ldots \ldots$

APPENDIX A QUESTIONNAIRES . . . . . . . . . . . . . . A-1

APPENDIX B. ANNUAL COST AVOIDANCE $\ldots \ldots \ldots \ldots \ldots \ldots \ldots \ldots$ B-1 



\section{TABLES}

1. Summary of the availability and other commitments of the Waste Reduction Coordinators ...................... 5

2. Pollution prevention accomplishments of the ER site

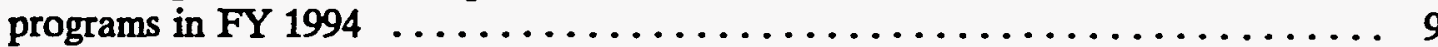

3. Site pollution prevention programs in which the ER Waste

Minimization and Pollution Prevention Awareness Program participates . . . . . 15 



\section{ACRONYMS}

$D \& D$

DOE

Energy Systems

ER

ERWM

NEPA

ORNL

ORO

ORR

PCB

PPE

PPOA

RA

RI

SMART

TDEC

USEC decontamination and decommissioning

U.S. Department of Energy

Martin Marietta Energy Systems, Inc.

Environmental Restoration

Environmental Restoration Waste Management

National Environmental Policy Act of 1969

Oak Ridge National Laboratory

Oak Ridge Operations

Oak Ridge Reservation

polychlorinated biphenyl

personal protective equipment

Pollution Prevention Opportunity Assessment

remedial action

remedial investigation

specific, measurable, assignable, realistic, and time-oriented

Tennessee Department of Energy and Conservation

United States Enrichment Corporation 



\section{EXECUTIVE SUMMARY}

The Environmental Restoration (ER) Program within Martin Marietta Energy Systems, Inc. (Energy Systems) is currently developing a more active waste minimization and pollution prevention program based on guidance from the U.S. Environmental Protection Agency and U.S. Department of Energy. To determine areas of programmatic improvements within the ER Waste Minimization and Pollution Prevention Awareness Program, the ER Program required an evaluation of the program across the Oak Ridge K-25 Site, the Oak Ridge National Laboratory, the Oak Ridge Y-12 Plant, the Paducah Environmental Restoration and Waste Minimization Site, and the Portsmouth Environmental Restoration and Waste Minimization Site. During the fourth quarter of FY 1994, a self-assessment was completed that centers on FY 1994 activities and presents the status of the ER Waste Minimization and Pollution Prevention Awareness Program

The assessment was conducted by distributing questionnaires to the ER Division Pollution Prevention Representative and the ER Waste Reduction Coordinators at each site. In addition, many of the participants were interviewed. The participants' response to the questionnaires was $100 \%$.

The data collected from the questionnaires were reviewed against four objectives:

- pollution prevention program structure standards,

- Energy Systems waste minimization and pollution prevention plans,

- interaction with site waste minimization and pollution prevention programs, and

- volume and cost reductions resulting from waste minimization activities.

This document presents the status of the overall program as of fourth quarter FY 1994, presents pollution prevention cost avoidance data associated with FY 1994 activities, and identifies areas for improvement. Results of this assessment indicate that the ER Waste Minimization and Pollution Prevention Awareness Program is firmly established and is developing rapidly. Several procedural goals were met in FY 1994 and many of the sites implemented ER waste minimization options. Additional growth is needed, however, for the ER Waste Minimization and Pollution Prevention Awareness Program. Significant portions of the ER Program are not participating in the ER Waste Minimization and Pollution Prevention Awareness Program at this time. The ER off-site projects and all projects associated with the five sites should be encouraged to participate in pollution prevention efforts. Additional guidance and training should be given to the Paducah and Portsmouth sites in order to have a consistent approach to pollution prevention across all sites. To ensure volume and cost reductions associated with pollution prevention efforts, a process of establishing goals within the ER Waste Minimization and Pollution Prevention Awareness Program should be refined and formalized. 


\section{INTRODUCTION}

The ER Program within Energy Systems manages remedial action (RA) and decontamination and decommissioning (D\&D) activities associated with the U.S. Department of Energy (DOE)-Oak Ridge Operations (ORO) ER OR-1 Project. Sites associated with this project include the Oak Ridge K-25 Site, the Oak Ridge National Laboratory (ORNL), and the Oak Ridge Y-12 Plant in Oak Ridge, Tennessee [collectively termed the Oak Ridge Reservation (ORR)]; the Paducah Environmental Restoration and Waste Management (ERWM) Site in Paducah, Kentucky; and the Portsmouth ERWM Site in Piketon, Ohio.

The ER Program includes a Waste Minimization and Pollution Prevention Awareness Program, which addresses pollution prevention within the DOE-ORO ER OR-1 Project work. The Waste Minimization and Pollution Prevention Awareness Program Plan for DOE-ORO's Environmental Restoration OR-1 Project: FY 1994-FY 1995 (ER Plan), ES/ER/TM-124, was developed to define the elements of the ongoing waste minimization and pollution prevention program. As a tenant of the ORR sites, however, the ER Division is also required to participate in the site waste minimization and pollution prevention programs at all locations. The site programs include a wide range of activities and are directed toward regulatory compliance applicable to the sites.

The ER Program within Energy Systems is currently developing a more active waste minimization and pollution prevention program based on guidance from the U.S. Environmental Protection Agency and DOE. To determine the areas where programmatic improvements could lead to improved cost efficiency and protection of human health and the environment, the ER Program required an evaluation of its current Waste Minimization and Pollution Prevention Awareness Program across the ORR and the Portsmouth and Paducah sites.

During the fourth quarter of FY 1994, a self-assessment centering on FY 1994 activities was undertaken. The self-assessment included a data gathering effort followed by an analysis of critical areas. This document summarizes the self-assessment approach, presents the status of waste minimization and pollution prevention activities within the ER Program as of fourth quarter FY 1994, presents pollution prevention cost avoidance information, and identifies areas for improvement associated with the ER Waste Minimization and Pollution Prevention Awareness Program. 


\section{METHODOLOGY}

The approach undertaken for the ER waste minimization and pollution prevention selfassessment included a data gathering phase followed by an evaluation phase as described below.

\section{DATA GATHERING}

Data gathering consisted of data collection and documentation accomplished simultaneously through the use of questionnaires. Two questionnaires were developed specifically for this FY 1994 self-assessment and are included as Appendix A. Questionnaire 1, General Site Pollution Prevention Program, was directed toward ER Program personnel who interface with the management organizations at each site. This questionnaire focused on management support to the ER waste minimization and pollution prevention activities, as well as integration between the site pollution prevention programs and the ER Waste Minimization and Pollution Prevention Awareness Program. Questionnaire 2, ER Pollution Prevention Protocol, was directed toward ER personnel with waste minimization and pollution prevention responsibilities at the sites. This questionnaire focused on the implementation of the ER Waste Minimization and Pollution Prevention Awareness Program at each location.

The questionnaires were distributed to ER personnel on August 30 and 31, 1994. Questionnaire 1 was presented to the ER Division Pollution Prevention Representative. Questionnaire 2 was presented to the ER Waste Reduction Coordinator associated with each RA site program, each D\&D site program, or in the case of Portsmouth and Paducah, the ERWM program. Completed questionnaires were either telefaxed to Radian or Radian personnel interviewed the participants in order to document responses on the appropriate questionnaire. All ER Program personnel who received questionnaires provided responses.

\section{EVALUATION PROTOCOL}

The ER Waste Minimization and Pollution Prevention Awareness Program was evaluated against four objectives:

- pollution prevention program structure standards,

- Energy Systems waste minimization and pollution prevention plans,

- interaction with site waste minimization and pollution prevention programs, and

- volume and cost reductions resulting from waste minimization activities.

The data collected were reviewed in terms of meeting the above objectives. In doing so, the performance of the ER Waste Minimization and Pollution Prevention Awareness Program was assessed against recognized standards as well as the program's goals. In addition, FY 1994 accomplishments were analyzed in terms of volume and cost reduction, where appropriate. 


\section{RESULTS}

Performance evaluation through a self-assessment process is a recognized pollution program element. ${ }^{1}$ This FY 1994 self-assessment is a "snapshot in time" of the current ER Waste Minimization and Pollution Prevention Awareness Program. In doing so, this selfassessment fulfills, in part, documentation of the evaluation or continuous improvement process by providing an analysis of critical areas and suggestions for improvements based on FY 1994 data.

The results of this FY 1994 self-assessment are discussed below in terms of the program's management and infrastructure, implementation, internal consistency, integration with the site programs, and an evaluation of volume and cost reduction. As the ER Waste Minimization and Pollution Prevention Awareness Program has incorporated pollution prevention program structure standards within its program plan, the document that defines the goals and policies for the program, the analysis of many of these critical areas can be found in the discussion pertaining to the program implementation (Sect. 3.2).

\subsection{PROGRAM MANAGEMENT AND INFRASTRUCTURE}

Successful waste minimization and pollution prevention programs have an infrastructure that encourages and supports prevention efforts and activities. ${ }^{2}$ A successful program is a combination of a cultural commitment to waste minimization and pollution prevention, demonstrated through the establishment of goals that promote effective and coordinated personnel policies and procedures, in addition to the resources necessary to implement the program. A successful program also includes a coordinated awareness and involvement of personnel through training, participation, and incentives.

\subsubsection{Management Commitment}

Active leadership is essential in the establishment of both visionary goals and practical goals. The communication of visionary goals may be through signed statements issued by management. The site pollution prevention programs have published policy statements that indicate the intent of management to support pollution prevention. The only existing policy statement for the ER Waste Minimization and Pollution Prevention Awareness Program is one that was published several years ago, in an ER pollution prevention program document, that was signed by J. T. Grumski, then head of Central ER's Technical Integration. The ER Division Pollution Prevention Representative has recently revised the ER policy statement, however, for the ER Director's signature.

Both the ORNL ER and the Y-12 ER Waste Reduction Coordinators are familiar with existing signed policy statements. Input from the Y-12 ER Program indicates that funding is lacking to back up the policy. A suggestion was made by a Waste Reduction Coordinator that a DOE pollution prevention counterpart needs to be established for the ER Waste Minimization and Pollution Prevention Awareness Program in order to provide needed support, similar to the role that a DOE counterpart plays in the ORR site pollution prevention programs. The K-25 ER and the Paducah ER programs are currently not aware of the existence of any policy statements. The Portsmouth ER Program is aware of 
management's commitment through the signed policy statement incorporated in the Portsmouth Waste Minimization and Pollution Prevention Plan, Revision III (POEF-2084).

In order to ensure communications regarding management's commitment to pollution prevention, the revised ER policy statement should be signed and incorporated into the ER Plan.

\subsubsection{Establishment of goals}

Management's establishment of specific, measurable, assignable, realistic, and timeoriented (SMART) goals is an important component of a pollution prevention program. Three general objectives are outlined in the ER Plan: (1) institutionalize pollution prevention within the ER Program, (2) reduce releases of hazardous and toxic materials, and (3) achieve operating economy and efficiency. Planned activities are presented in terms of FY 1994 and FY 1995 time frames. Input from the Y-12 RA program indicated that such a general schedule without fixed dates is appropriate for ER activities since the activities currently planned are procedural in nature and do not require quantitative results.

While procedural goals are appropriate for meeting the broad objective of institutionalizing waste minimization as an element in the $R A$ and $D \& D$ process, quantitative goals are necessary to meet the additional two objectives in the ER Plan: (1) protecting human health and the environment by reducing releases of hazardous and toxic material and (2) achieving operating economy and efficiency by applying the principles of waste minimization.

Quantitative goals are realized through the assessment of baseline data. Baseline information allows the data user to interpret the current implementation status and predict future outcome of waste minimization activities. Baseline data to measure progress exist for both the ORNL D\&D Program and the Y-12 D\&D Program but is not included in the ER Plan. The ORNL D\&D baseline is incorporated into their life-cycle baseline budgeting exercise and is reported by waste type and waste category within their life-cycle baseline documentation. The Y-12 D\&D Program has an internally-used baseline that resulted from an engineering estimate to calculate the waste stream generation forecast for all three phases of the 9201-4 project. This information was provided to Central ERWM. Baseline data do not exist for the remaining ER programs. One respondent stated that the ER Plan should include an action plan that incorporates a baseline, goals, and specific steps to achieve these goals.

A process for periodically setting SMART goals needs to be established within the ER Waste Minimization and Pollution Prevention Awareness Program. This process should incorporate the basic steps of problem solving: baseline data collection, data evaluation and option assessment, tracking and reporting, and evaluation and should be formalized in the ER Plan.

\subsubsection{Establishment of resources}

In order to realize goals, appropriate resources to staff, organize, and maintain the program are essential. According to the ER Plan, the ER Division Waste Reduction Manager is responsible for leading the waste minimization and pollution prevention effort at the programmatic level. Each site has a ER Waste Reduction Site Representative and each RA 
program and D\&D Program or ERWM Program have Waste Reduction Coordinators to implement waste reduction activities.

The ER Plan outlines the responsibilities of the ER Division Waste Reduction Manager, the Waste Reduction Coordinator, and the Waste Reduction Site Representative. All the Waste Reduction Coordinators have copies of the ER Plan; however, results from the assessment indicate that one of the coordinators has a plan that is missing several pages. In general, responses from the assessment participants indicated that roles and responsibilities of the Waste Reduction Coordinator are not well understood or accepted. One respondent indicated that his roles and responsibilities as a waste reduction coordinator are not included in his job description and another responded that the responsibilities have not been formally addressed.

Although one respondent indicated that he was aware of the Waste Reduction Coordinator's responsibilities, he stated that the ER Division Waste Reduction Manager is responsible for some of those activities since the Waste Reduction Coordinator does not have the necessary personnel and resources. Another respondent stated that the role and responsibilities of the Waste Reduction Coordinator are understood by that individual, but they are not being implemented at the moment. The responsibilities are viewed as reasonable, except for the preparation of a newsletter. A separate newsletter for pollution prevention activities for the ER site activities is considered unnecessary since there is a plant newsletter, and the ER pollution prevention activities are sporadic.

Confusion exists regarding the roles and responsibilities of the Waste Reduction Coordinators. Roles and responsibilities may need to be communicated through training that includes discussions of applicable sections of the ER Plan.

The Waste Reduction Coordinators all have additional responsibilities that need to be continuously met. Several Waste Reduction Coordinators stated that they need more time for waste minimization and pollution prevention activities. Table 1 summarizes the Waste Reduction Coordinators' availability and other commitments.

Table 1. Summary of the availability and other commitments of the Waste Reduction Coordinators

\begin{tabular}{lcl}
$\begin{array}{c}\text { Waste Reduction } \\
\text { Coordinator }\end{array}$ & $\begin{array}{c}\text { Time spent } \\
(\%)\end{array}$ & \multicolumn{1}{c}{ Other duties } \\
\hline K-25 RA & $30-50$ & $\begin{array}{l}\text { Health and safety oversight; interface for K-25 Site } \\
\text { disciplines and subcontractors for all RA projects, } \\
\text { including site surveillance and health and safety plan } \\
\text { development } \\
\text { D\&D Project Manager Phase II Coordination }\end{array}$ \\
K-25 D\&D & 5 & $\begin{array}{l}\text { ER Environmental, Safety, and Health Manager; ER } \\
\text { ORNL Waste Management Manager; Radiation } \\
\text { Control Officer; Environmental Protection Officer }\end{array}$ \\
ORNL D\&D & 25 & Project management for facility transition
\end{tabular}


Table 1 (continued)

\begin{tabular}{lcl}
\hline $\begin{array}{c}\text { Waste Reduction } \\
\text { Coordinator }\end{array}$ & $\begin{array}{c}\text { Time spent } \\
(\%)\end{array}$ & \multicolumn{1}{c}{ Other duties } \\
\hline Y-12 RA (2 individuals) & 25 each & $\begin{array}{l}\text { One individual has project management } \\
\text { responsibilities, including heiping the site manager } \\
\text { implement the new ER Focus Area Task. Another } \\
\text { individual has responsibility for Resource } \\
\text { Conservation and Recovery Act activities, including } \\
\text { inspecting waste accumulation areas; also involved in } \\
\text { building coordination and transporting visitors }\end{array}$ \\
Y-12 D\&D & $10-15$ & $\begin{array}{l}\text { Program interface for Waste Management, Risk } \\
\text { Assessment, National Environmental Policy Act of } \\
\text { 1969 (NEPA), safety document. }\end{array}$ \\
& 5 & $\begin{array}{l}\text { Environmental Compliance Coordinator, Pollution } \\
\text { Prevention Coordinator, Comprehensive } \\
\text { Environmental Response, Compensation, and Liability } \\
\text { Act interface }\end{array}$ \\
& & $\begin{array}{l}\text { Responsible for the site-wide pollution } \\
\text { prevention/waste minimization program and day-to- } \\
\text { day pollution prevention projects }\end{array}$ \\
\hline
\end{tabular}

As Table 1 shows, a wide range of duties competes for the attention of the Waste Reduction Coordinators.

According to the survey participants, only the Portsmouth program includes specified funding for ER waste minimization and pollution prevention activities. In general, project managers decide how much funding is required for pollution prevention on each individual project. For the Y-12 D\&D Program, waste minimization and pollution prevention activities are viewed as an integral part in the planning phase to minimize cost and waste. As such, no specific funding has been identified, although pollution prevention activities and options were incorporated in the engineering assessment of the 9201-4 D\&D project. One respondent indicated that there is no funding for pollution prevention training, supplies, or specific activities. However, the individual recognizes that funds are available in Defense Programs that may be obtained for pollution prevention activities. Currently, there is no guidance in place for accessing these funds. A recommendation of this assessment is to document and communicate the process in the ER Plan for obtaining funds from alternative sources.

It is recommended that an analysis of the roles and responsibilities assumed by the individuals designated as Waste Reduction Coordinators be undertaken to determine where additional resources may be needed. Currently, most of these individuals have many competing priorities.

An additional area for improvement concerns the role of the project manager within the ER Program. Since the project manager funds pollution prevention activities that are undertaken within the context of a larger project, it is important for the project manager to be cognizant of the ER Pollution Prevention and Waste Minimization Awareness Program. 
An ER pollution prevention awareness initiative that includes training, involvement, and incentives should be directed at project managers.

\subsubsection{Sponsorship of prevention activities}

Management's sponsorship of pollution prevention activities is an important component of a successful program. This sponsorship may be formalized through procedures, the support of new technologies, new applications of existing technologies, or documented strategies. The Waste Reduction Coordinators identified the following procedures as being applicable to their pollution prevention activities: the waste management plan in the ER Guidance Document to Prepare Waste Management Plans (ORNL/ER-148), the ER Program Pollution Prevention Checklist (ES/ER/TM-89), the Y-12 Plant Pollution Prevention Program (Y/73-11), and Waste Minimization and Pollution Prevention Awareness Program Plan, Revision III (POEF2084). In addition, the Energy Systems Procedure for the preparation of ER task/project specific waste management plans (ER/C-P2101) requires waste minimization and reduction techniques to be implemented.

The responses varied as to the support of new technologies or new applications of existing technologies. It was generally agreed that the ER Plan addresses technology needs but does not include a specific method of identifying technologies beyond the Pollution Prevention Opportunity Assessment (PPOA) process, nor does it include an evaluation of new technologies. The Y-12 D\&D Program is currently screening new and existing technologies as part of their Engineering Assessment/Cost Evaluation pertaining to the 9201-4 D\&D project. The ER Division Waste Reduction Manager is currently funding a study, due out at the end of FY 1994, to identify the major technology resource agencies that could potentially fill ER technology needs. The purpose of the study is to provide project personnel with a list of organizations that could provide waste minimization and pollution prevention technology, either off-the-shelf or newly developed, and to provide the means for accessing those organizations when needed.

Material reuse strategies and information and technology exchange activities are ongoing at some ER sites; however, the overall strategies are generally unknown at this time. One respondent stated that a specific procedure for material reuse for ER activities is necessary. It was also stated that coordination with other plants is needed in this area. Another respondent stated that common sense approaches are applied for the reuse of equipment and materials and indicated that this approach has been successful.

Results from this assessment indicate that more communication is needed in the area of implementing pollution prevention activities. As the waste reduction coordinators are using different procedures, they need to evaluate as a group which procedures are effective and work to improve and standardize their procedures. A starting point for this discussion could be the evaluation of the ER Program Pollution Prevention Checklist that is used by the Y-12 RA program.

It is also important for the results of the 9201-4 D\&D project and the ongoing technology study to be communicated when the information becomes available. In addition, successes in material reuse strategies and information and technical exchange activities should be discussed among the Waste Reduction Coordinators. A strategy for material reuse as well as a mechanism for communicating material reuse experiences should be developed and documented in the ER Plan. 


\subsubsection{Employee Involvement}

Awareness programs implemented on an ongoing basis increase employee involvement and commitment. At this time, no formal ER pollution prevention awareness activities are in place. Instead, ER personnel participate in site awareness activities on a voluntary basis that may be coordinated through a designated ER person at each site. Examples of these types of awareness participation are the annual site awareness month, the Environmental Fair, and Earth Day activities. For the ORNL RA program, pollution prevention awareness is incorporated into the project waste management plans. These plans require training for anyone generating solid low-level waste. At Portsmouth, awareness activities include General Employee Training and periodic articles submitted to "The Open Line," the site daily publication, in addition to project-specific training.

Employee training in pollution prevention is currently not formalized within the ER Program. Three Waste Reduction Coordinators relayed that they attended a pollution prevention workshop at Oak Ridge in July 1994 that was focused on the ER Program. One Waste Reduction Coordinator attended the annual DOE pollution prevention conference in Denver, Colorado. Two Waste Reduction Coordinators indicated that they did not participate in any pollution prevention training this year.

Three Waste Reduction Coordinators discussed FY 1994 training opportunities at the site level. The ORNL RA Waste Reduction Coordinator and all site workers attended lowlevel waste generator training. The Y-12 RA Waste Reduction Coordinators attended office paper recycling and PPOA training. These training sessions were held during the lunch hour and were not required. The K-25 RA Waste Reduction Coordinator has viewed module number 7212 of the K-25 Site Pollution Prevention-required video and has received training for Waste Certification Officers and Low-Level Solid Waste Generators. All K-25 ER personnel will receive the K-25 Site Pollution Prevention Program video training.

One Waste Reduction Coordinator stated that specialized ER PPOA training is needed for the project managers, the subcontractors, and the ER Prime contractors. He suggested that specific training should be given at each project phase [e.g., remedial investigation (RI), feasibility study, and RA].

It is recommended that goals for ER Waste Minimization and Pollution Prevention Awareness Program training be established and should include ongoing training for the Waste Reduction Coordinators, as well as the sponsorship of pollution prevention training for project managers, as discussed in Sect. 3.1.2.2.

Employee incentives within the ER Program were evaluated in terms of job performance considerations, contractual requirements, and the awards program. All respondents but one, who did not know, indicated that evaluations of job performance do not take into consideration the accomplishment of pollution prevention objectives.

At the ORNL RA program, contractors are required to perform work that also serves to implement pollution prevention activities. This is formalized in the waste management plans that all contractors are required to write. The same general approach was mentioned as being followed for the Y-12 RA program. At the K-25 ER Program, incorporating pollution prevention provisions into contracts with subcontractors has been discussed, but procurement has not been directed to incorporate such requirements in the subcontracting 
process. At the Y-12 D\&D, Paducah, and Portsmouth programs, provisions are not included in existing contracts. The respondent for the ORNL D\&D Program was not sure of the provisions in existing contracts.

At both Paducah and Portsmouth, no local site incentive and awards program is in place. No ER-specific awards program is in place at the ORR, and participation in the site awards programs is not generally known. An exception is at the Y-12 RA program where the Kerr Hollow project was nominated in the site awards program. It was communicated, in general, that the Y-12 Plant does not consider some ER activities as pollution prevention but rather as waste disposal or storage, which effectively discourages ER Program participation in the awards program. It was reported that the existing K-25 Site pollution prevention program and awards/recognition system is used sporadically by $\mathrm{K}-25 \mathrm{ER}$.

It is recommended that management should promote ER involvement in the site awards programs, while heightening the awareness of the administrators of the awards programs through communication of the characteristics of ER pollution prevention activities. At the individual level, job performance indicators should include SMART pollution prevention goals as part of the performance review process in order to provide additional incentives for pollution prevention within the ER Program.

\section{PROGRAM IMPLEMENTATION}

The implementation of the ER Waste Minimization and Pollution Prevention Awareness Program was reviewed against policies, strategies, objectives, and goals set out in the ER Plan. In addition, the waste reduction coordinators were queried as to FY 1994 pollution prevention accomplishments. This assessment yielded the accomplishments provided in Table 2.

Table 2. Pollution prevention accomplishments of the ER site programs in FY 1994

\begin{tabular}{|c|c|}
\hline Program & Accomplishments \\
\hline K-25 RA & $\begin{array}{l}\text { Polychlorinated biphenyl (PCB) capacitors are segregated as radiologically } \\
\text { contaminated or non-radiologically contaminated. PCB capacitors are sent off-site } \\
\text { for incineration, while remaining contaminated PCB capacitors must be stored for } \\
\text { future disposal. The K-25 RA program negotiated a change in the Tennessee } \\
\text { Department of Environment and Conservation (TDEC) corrective action for the } \\
\text { K-1407-B and C Ponds. This resulted in the cancellation of equipment } \\
\text { decontamination requirements and in a large reduction in the waste for the project }\end{array}$ \\
\hline
\end{tabular}

K-25 D\&D Scrap metals are segregated and sent to SEG's Metal Melt Facility if radiological and low-level contaminated, sold to buyers for outside use if not radiological contaminated through the Surplus Materials program, or stored for future use or disposal

ORNL RA Recycling/regeneration of decontamination water Use of smaller diameter augers to reduce drilling wastes and sample collection waste.

ORNL D\&D None. Activities to date have only included characterization efforts that do not provide real opportunity for waste minimization 
Table 2 (continued)

\begin{tabular}{|c|c|}
\hline Program & Accomplishments \\
\hline Y-12 RA & $\begin{array}{l}\text { The Reduction of Mercury in Plant Effluent project and personal protective } \\
\text { equipment (PPE) reduction. ER also participates in the ER Waste Reduction } \\
\text { Council }\end{array}$ \\
\hline Y-12 D\&D & $\begin{array}{l}\text { By rescheduling work hours for the } 9201-4 \text { project, the amount of PPE was } \\
\text { essentially reduced by half. } 2500 \text { gal of decontamination water was recycled and } \\
\text { reused to minimize the amount of waste stream generated }\end{array}$ \\
\hline Paducah & None \\
\hline Portsmouth & Started Waste Minimization Team meetings \\
\hline
\end{tabular}

A comparison of the above accomplishments against the planned activities in the ER Plan indicates that several of the RA and D\&D Programs had a more ambitious FY 1994 pollution prevention program than anticipated. For FY 1994 goals, the ER Plan included conducting a PPOA on disposal of personal protective clothing. As the above shows, the K-25 RA, the K-25 D\&D, the ORNL RA, the Y-12 RA, and the Y-12 D\&D Programs all surpassed the FY 1994 goals by actually implementing minimization programs.

At the ER Program level, several ER Plan FY 1994 objectives were met:

- An ER Waste Reduction Council was established.

- A waste minimization and pollution prevention awareness program plan was published.

- A computer-based training module for ER waste minimization and pollution prevention general awareness was developed.

As discussed in Sect. 3.1.2.1, the establishment of SMART goals is an important component of a program's ability to accomplish objectives. The ER Waste Minimization and Pollution Prevention Awareness Program was reviewed against key planning and decisionmaking elements and, in doing so, current status and areas for improvements were identified. These areas are summarized below by the problem solving components of pollution prevention: baseline data collection, data evaluation and option assessment, tracking and reporting, and program evaluation.

\subsubsection{Baseline Data Collection}

Each Waste Reduction Coordinator was queried as to the existence of baseline data for waste stream generation. No baseline estimates are presented in the ER Plan and no method is currently in place for generating baseline data within the program. Nonetheless, the ORNL D\&D Program and the Y-12 D\&D Program have both independently established baseline data. The baseline estimates for the ORNL D\&D Program are reported by waste type and waste category and are formalized in their Life-cycle Baseline Detailed Project Report. This information is provided to ERWM personnel but has not been used to establish specific goals. For the Y-12 D\&D Program, an engineering estimate was utilized to calculate the waste stream generation forecast for all three phases of the 9201-4 project for ERWM personnel. 
Baseline data as they exist now, consist of life-cycle projections for individual projects. One respondent observed that specific goals cannot be set without the establishment of consistent baseline data. He has instead implemented a numerical scoring system, where points are given for each pollution prevention measure implemented. At all the ER programs, no quantitative waste stream reduction goals exist. As recommended in Sect. 3.1.1.1, baseline data need to be established within the ER Waste Minimization and Pollution Prevention Awareness Program. It is recommended that a method for generating baseline data be established and implemented.

\section{Data Evaluation and Option Assessment}

As baseline data collection is lacking, it was not surprising that no formalized system is in place to generate pollution prevention options. The ER Plan specifies that PPOAs are to be used to generate options, but PPOAs are not currently implemented within the program. In fact, one respondent did not know what PPOAs were until a few months ago.

Although recognized methods for data evaluation and option assessment do not exist within the ER Program, pollution prevention is being incorporated into RA, D\&D, and NEPA activities at many of the ER locations. Within the ORNL RA and the K-25 D\&D Program, opportunities for pollution prevention are identified regularly, but informally. Within the ORNL RA program, options are generated by brainstorming between site workers and project managers. In doing so project managers involve workers in waste minimization activities on a day-to-day basis. The waste management plans and daily briefings of site personnel from project managers both serve to incorporate pollution prevention into RA activities. As a result, waste minimization and pollution prevention is being continually realized. The ORNL RA Waste Reduction Coordinator stated that wastes minimization achievements are not compared from year to year using quantitative data due to the lack of available personnel and resources.

In the K-25 D\&D Program, waste minimization practices and project technologies are identified during the development of the work plans and project waste management plans. Harvesting of reusable and recyclable materials is conducted within the project life cycle as routine operations. The K-25 ER Program is reluctant to participate in PPOAs for D\&D projects unless PPOAs are mandated by DOE Orders or milestones, and only if PPOAs can be demonstrated as "value-added."

The Y-12 ER Program follows a varied approach to option identification. At the Y-12 RA program, options are generated using activity sheets and value engineering. The activity sheets are used as a communication tool to make others aware of pollution prevention activities associated with a project. Although the ER Division Waste Reduction Manager is disseminating guidance on PPOAs, the Y-12 RA Waste Reduction Coordinator stated that a level four procedure is needed to support the guidance. In general, pollution prevention is incorporated into Y-12 RA activities using checklists. Pollution prevention is also incorporated into Y-12 RA activities through work plans. A concern communicated by the Waste Reduction Coordinator is that the project managers are instrumental in guiding pollution prevention efforts but are not trained in pollution prevention. Neither the ER Focus Area Task Training nor the Energy System Task Based Management Training, which are given to project managers, include pollution prevention concepts. 
The Y-12 D\&D Program generates pollution prevention options through cost savings ideas, best management practices, and a "common sense approach." To minimize costs, options are included as an integral part of best management practices. The Y-12 D\&D Program has a PPOA on PPE planned for FY 1994.

At Portsmouth, no PPOAs have been conducted, and the Waste Reduction Coordinator was not aware of any planned for FY 1995. In general, pollution prevention options are generated through engineering design and review of procedures and waste generation plans. Pollution prevention tends to be incorporated into RA and D\&D activities at the project managers' or engineers' discretion. Soon all waste generators will be required to submit a waste generator's management plan, which must contain pollution prevention and waste minimization initiatives.

Pollution prevention is being incorporated into the NEPA process at all ER locations through a NEPA checklist that asks whether waste minimization and pollution prevention concerns have been addressed.

As discussed previously, the project managers should be trained in the ER waste minimization program since they are responsible through funding and direction for implementing pollution prevention within their projects. In addition, a review of the appropriate method for generating options within the ER Waste Minimization and Pollution Prevention Awareness Program needs to be evaluated since there are differences among the ER participants on the approach.

Currently, volume and cost reductions associated with pollution prevention are not being addressed, nor is there recognized method in place to do so. It is recommended that a method for communicating volume and cost reduction be established so that ER Waste Minimization and Pollution Prevention Awareness Program successes can be consistently communicated.

\subsection{Tracking and Reporting}

Tracking and reporting activities are important components of a pollution prevention program since they allow for the measurement of success. The Waste Reduction Coordinators have tracking and reporting responsibilities as part of their responsibilities as outlined in the ER Plan, and a specific tracking system is also outlined in the ER Plan, yet information gained through this assessment indicates that no tracking and reporting system is in place. Nevertheless, Y-12 ER Program, the Paducah program, and the Portsmouth program all have a person designated as responsible for these activities. The K-25 ER Program and the ORNL ER Program do not have anyone designated beyond participation in the site programs.

At the Y-12 RA program, activity forms are used for tracking purposes, which include information on the type of waste stream feasibility of pollution prevention, possible techniques for reduction, and expected waste reduction. These forms are sent to the site-wide Pollution Prevention Coordinator but may also be useful to the ER Waste Minimization and Pollution Prevention Awareness Program, according the Waste Reduction Coordinator. In the Y-12 RA program, the Waste Reduction Coordinator is often requested to provide similar pollution prevention information to his three managers: the ER Program Manager, the site-wide Pollution Prevention Coordinator, and the ER Division waste reduction manager. If the reporting format were standardized, he believes the effort would be more efficient. 
The ORNL RA program uses the ERWM Program Generated Waste Form (\#UCN1961), but the forms are not evaluated as part of the ER Waste Minimization and Pollution Prevention Awareness Program, according to the Waste Reduction Coordinator. In the Y-12 D\&D Program, the building manager for Building 9201-4 is currently identifying and tracking D\&D activities associated with this project. At Portsmouth, the site waste minimization section manager is responsible for identifying and tracking ER pollution prevention activities. The Waste Reduction Coordinator is responsible for tracking and reporting at Paducah, but no system is in place.

The Waste Reduction Coordinators do not currently have clear roles and responsibilities associated with tracking and reporting activities. The tracking system outlined in the ER Plan needs to be communicated to the Waste Reduction Coordinators, and their tracking and reporting responsibilities associated with this system need to be defined. In addition, support needs to be provided to the Waste Reduction Coordinators for ad hoc reporting. It is clear that some reporting needs can be anticipated, and standardized to provide for increased efficiency in the Waste Reduction Coordinators activities.

\subsection{Program Evaluation}

Waste minimization and pollution prevention should be a process of continuous improvement. ${ }^{3}$ When considering the ER Program's goal of increased efficiency and economy of waste management activities during $R A$ and $D \& D$ activities, continuous improvement becomes a critical element of the program. As discussed previously, measurements of increased efficiency and economies are not possible due to the lack of baseline data collection, data evaluation, and tracking and reporting activities.

Program evaluation through self-assessments is addressed in the program's planned activities set out in Table 1 of the ER Plan, and this assessment meets that general objective. In addition to annual self-assessments, it is important for ongoing assessments of the program to take place throughout the year using the recognized tools of problem solving: baseline data collection, data evaluation and option assessment, tracking and reporting activities, and routine evaluations of progress. A recommendation is to formalize these steps through written guidance and the documentation of routine evaluations.

\subsection{CONSISTENCY WITHIN THE PROGRAM}

\subsubsection{Current Status}

Information obtained via questionnaire from the Waste Reduction Coordinators provided the opportunity to gain a candid view of the ER Waste Minimization and Pollution Prevention Awareness Program. It is safe to say that at all locations waste minimization and pollution prevention initiatives are developing in accordance with the degree of attention given to the programs by individual ER project managers. There is a pattern for the emergence of these initiatives, and it shows clearly that waste minimization and pollution prevention activities within the three Oak Ridge plant RA programs are substantially advanced in comparison to activities at Portsmouth, Paducah, and within the three D\&D programs in Oak Ridge. One probable reason for this difference between RA and D\&D programs stems from the several years of active RI programs within ORR and the need to minimize waste associated with field activities (investigation derived waste and PPE). 
Examples of this include the use of smaller borehole augers and the reuse of PPE free of radioactivity. In the $D \& D$ programs, waste minimization and pollution prevention initiatives should receive more attention now that D\&D characterizations are being completed and demolition activity will be undertaken in the next few years.

Not all of the RA and D\&D projects in Oak Ridge participate in the ER Waste Minimization and Pollution Prevention Awareness Program. The off-site projects and some of the Oak Ridge on-site RA projects are not incorporated into the program at this time. Given that these projects may account for a large portion of ER-managed waste, it is important that waste minimization and pollution prevention initiatives be extended to these potentially significant activities.

Following the split of both the Paducah and Portsmouth sites into United States Enrichment Corporation (USEC)-managed and DOE-managed facilities, many of the existing programs, personnel, and resources went to USEC. As a result, many programs are being restarted with the ERWM programs, including the waste minimization program.

The ER Plan is distributed at all ER locations; however, well defined ownership of the responsibilities for all aspects of the program that is outlined in the plan is not clearly understood by all. The existence of the general objectives of the program is generally understood, and almost everyone participates in plant-wide recycling programs, but only one or two specific ER pollution prevention initiatives have been carried out, and these are at the ORR.

There is a mixed attitude toward the use of certain tools, such as the PPOAs. Few have been completed and the planned use is sporadic. One organization will not participate unless they are mandated via DOE Orders or milestones, or unless they represent "value added" over current approaches. Almost all the RA and D\&D Waste Reduction Coordinators feel there is considerable competition for their time and attention, and PPOAs represent another layer of work with limited perceived value. To others, the concept of PPOAs is completely new.

There are few known incentives to encourage employee participation in the ER Waste Minimization and Pollution Prevention Awareness Program. Also, there are no known specific incentives for pollution prevention included in Energy Systems subcontracts, although there is widespread interest in such. At one facility, subcontractors are responsible for waste minimization and pollution prevention initiatives activity through requirements in the waste management plan for each on-site activity. No individual reported any existing program whereby an employee's performance review includes any consideration for pollution prevention accomplishments.

Very little readily identifiable ER Waste Minimization and Pollution Prevention Awareness Program tracking is ongoing. However, there are systems within the ER Program with this capability that are referenced in the ER Plan. For example, the current waste generation tracking system used in Central ERWM Technical Integration and Planning may be utilized for the tracking of specific ER Waste Minimization and Pollution Prevention Awareness Program goals. 


\subsubsection{Areas for Waste Minimization and Pollution Prevention Program Improvement}

Advancements in the ER waste minimization and pollution prevention initiatives will become the norm as more specific programmatic requirements are developed. As this occurs, special attention should be given to developing guidance, methods and procedures that entail a minimum of bureaucracy. Through the establishment of SMART goals that include incentives for managers, staff, vendors, and subcontractors, advancements will occur. Any programmatic development, whether policy, procedure, training, tracking, or demonstrations, needs to be administered uniformly across the ER Waste Minimization and Pollution Prevention Awareness Program.

The ER Plan should be updated annually with realistic and clearly stated goals for the current fiscal year. Near term milestones should be established and communicated. These milestones should be readily understood by the ER Division staff, and training should be carried out in a timely fashion so as to accomplish them. Additional guidance and training should be available to the Paducah and Portsmouth programs to grow their transitional programs.

The realistic baselining of objectives is not currently practiced within the ER Waste Minimization and Pollution Prevention Awareness Program. Some of the Waste Reduction Coordinators reference the Activity Data Sheet Life-Cycle Baseline Reports as the source for baseline data, but this is not a very likely source of such information. The life-cycle reports were developed to ensure adequate funding for remediation of various operable units, and waste minimization and pollution prevention is not within that scope. Baseline data need to be developed independent of these other funding documents, yet tied to specific RA and D\&D functions.

\subsection{INTEGRATION WITH THE SITE PROGRAM}

The Waste Reduction Coordinators indicate that integration of the ER Waste Minimization and Pollution Prevention Awareness Program and site pollution prevention programs is working well. (See Table 3.)

Table 3. Site pollution prevention programs in which the ER Waste Minimization and Pollution Prevention Awareness Program participates

\begin{tabular}{|c|c|}
\hline Location & Activities \\
\hline $\mathrm{K}-25$ & $\begin{array}{l}\text { The K-25 ER Program participates in plant recycling programs for paper and } \\
\text { aluminum cans; affirmative procurement, where possible; and reuse of materials and } \\
\text { equipment. Substitution of products has also been practiced. The division pollution } \\
\text { prevention representative's participation has included attendance in council } \\
\text { meetings, participation in pollution prevention Awareness Month, telephone book } \\
\text { recycling, and participation in pollution prevention program agenda as directed by } \\
\text { management and required by DOE Orders and federal and state regulations }\end{array}$ \\
\hline
\end{tabular}

ORNL RA participates in paper, aluminum can, and other office type waste recycling. The field activities also segregate waste. D\&D participates in paper, aluminum can, and other office type waste recycling, but only in certain facilities because of health physics concerns in some buildings 
Table 3 (continued)

\begin{tabular}{ll}
\hline Location & \\
\hline Y-12 & $\begin{array}{l}\text { Participation in the Y-12 program includes affirmative procurement, office and } \\
\text { mixed paper recycling, aluminum can recycling, and toner cartridge recycling. } \\
\text { Bernard Phifer from ER is a current member of the Y-12 Site Pollution Prevention } \\
\text { Council }\end{array}$ \\
Paducah & $\begin{array}{l}\text { Aluminum can recycling } \\
\text { Portsmouth }\end{array}$ \\
& $\begin{array}{l}\text { Plant-level includes cardboard recycling, paper collecting, and aluminum can } \\
\text { recycling }\end{array}$ \\
\hline
\end{tabular}

ER personnel also receive pollution training and guidance through the site programs. Overall, the ER Division is treated like any other generator at the sites. According to one respondent, this poses some difficulties in the areas of pollution prevention objectives and schedules. For example, the K-25 Site program bases their program goals on the formulas for waste reduction established in the Tennessee Hazardous Waste Reduction Act. However, that law specifically exempts remedial or corrective actions from some of its requirements.

It terms of schedules, the site pollution prevention programs do not specifically include the ER Division in the plant level schedules. It was stated by one respondent that the ER Division needs to independently schedule and report its own prevention activities. This independence is necessary due to the unique requirements of ER projects, including the necessity of meeting regulatory deadlines and the need to develop appropriate technologies for remediation and D\&D before waste minimization and pollution prevention options can be considered.

As discussed in Sect. 3.1.2, the site awards program is currently not geared toward ER activities. The program should be examined in light of this observation and appropriate measures should be taken to ensure ER participation.

\subsection{EVALUATION OF VOLUME AND COST REDUCTIONS}

The evaluation of volume and cost reductions resulting from pollution prevention activities is an essential element of a successful pollution prevention program. There is a need to demonstrate a return on investment for pollution prevention initiatives. As DOE's budget, and consequently funding for the ER Division continues to decrease, it becomes increasingly more evident that any program not able to demonstrate cost-effectiveness will meet its eventual demise. In addition, cost savings are important when disseminating information about pollution prevention ventures. Managers and decision makers continuously evaluate in fiscal terms, and cost information is required for comparison purposes.

As indicated by the survey responses, cost and volume reductions resulting from pollution prevention activities are not well known or quantified. No cost savings evaluations had been conducted for any of the waste minimization activities initiated by ER in FY 1994. One respondent did indicate that engineering assessments and cost evaluations are used to 
calculate waste generation forecasts for ERWM. This forecast does not, however, specifically evaluate the volume and cost reductions from implementing a specific waste minimization activity in comparison to maintaining the status quo.

Most respondents were not aware of any methodology for calculating waste reduction and associated cost savings. One method available is the Index of Annual Cost Avoidance 4 . The index provides a uniform, fair, and consistent system for determining the major costs associated with a current process/activity, determining the costs associated with the pollution prevention initiative, and comparing these costs. The index is a good tool for estimating the economic value and feasibility of a pollution prevention option. It provides an estimate of potential cost savings and estimates the pay back period; however it is not a substitute for lifecycle costing or other more detailed accounting procedures.

To provide concrete examples of evaluating cost and volume reduction, the Index of Annual Cost Avoidance method was employed for two of the pollution prevention projects mentioned by the waste reduction coordinators in the survey. The projects evaluated are the Y-12 D\&D PPE Reduction initiative and the ORNL RA Mobile Decontamination Trailer project.

For the Y-12 PPE reduction, the index method indicated that an approximate 50\% reduction in the use of PPE resulted in a cost savings of approximately $\$ 135,352$ in a 7 -month period. In addition, because of the low implementation cost of the PPE reduction initiative, the estimated payback period is a mere 5 days.

The index method was applied to the ORNL mobile decontamination trailer project and indicated that $\$ 16,750$ is avoided in a 3 -week period by recycling/regenerating decontamination water. Assuming that the mobile trailer would be used on a continual basis, the payback period for this pollution prevention initiative would be 0.6 years.

The completed Index of Annual Cost Avoidance worksheets used to derive the volume and cost reductions are included in Appendix B. 


\section{CONCLUSION}

This FY 1994 self-assessment of the ER Waste Minimization and Pollution Prevention Awareness Program identified many successes associated with this developing program and several areas for improvement. In terms of the program's management and infrastructure, the assessment determined that procedural goals have been established for meeting the broad objective set out in the ER Plan of institutionalizing waste minimization as an element in the RA and D\&D process. In fact, many FY 1994 accomplishments have been realized to date associated with this broad objective. These accomplishments include the following:

- An ER Waste Reduction Council was established.

- A waste minimization and pollution prevention awareness program plan was published.

- A computer-based training module for ER waste minimization and pollution prevention general awareness was developed.

The assessment discovered, however, that SMART goals need to be established to meet the additional two objectives in the ER Plan: protecting human health and the environment by reducing releases of hazardous and toxic material and achieving operating economy and efficiency by applying the principles of waste minimization. A recommendation is to establish a process for periodically setting SMART goals that incorporate the basic steps of problem solving: baseline data collection, data evaluation and option assessment, tracking and reporting, and evaluation. This process should then be formalized in the ER Plan.

Results from this assessment indicate that several of the site programs had a more ambitious FY 1994 pollution prevention program than was projected in the ER Plan. Although SMART goals were not incorporated within the ER Plan, the RA and D\&D Program accomplished several waste minimization activities in FY 1994:

- The K-25 RA program negotiated a change in the TDEC corrective action for the K1407-B and $C$ Ponds. This resulted in the cancellation of equipment decontamination requirements and in a large reduction in the waste for the project.

- The K-25 D\&D Program segregated scrap metals and sent some to SEG's Metal Melt Facility, if radiological and low-level contaminated, or sold through the Surplus Materials program to buyers for outside use, if not radiologically contaminated.

- The ORNL RA program recycled and regenerated decontamination water. In addition, smaller diameter augers were used to reduce drilling wastes and sample collection waste.

- The Y-12 RA program implemented the Reduction of Mercury in Plant Effluent project and PPE reduction at one operable unit.

- The Y-12 D\&D Program rescheduled work hours to minimize the amount of PPE used. The amount was essentially reduced by half. In addition, 2500 gal of decontamination water was recycled and reused to minimize the amount of waste stream generated. 
The following accomplishments were evaluated further as part of this assessment and the cost reduction associated with them was calculated:

It was determined that the Y-12 D\&D PPE Reduction initiative would result in a cost savings of approximately $\$ 135,352$ in a 7 -month period. The ORNL RA Mobile Decontamination Trailer project was estimated to save $\$ 16,750$ in a 3-week period, if used continuously. It is recommended that an ongoing process to evaluate and communicate cost reductions be developed to assist in the measurement of program success.

An area for improvement identified by this assessment concerns the role of the project manager within the ER Program. Since the project manager funds pollution prevention activities that are undertaken within the context of a larger project, it is important for the project manager to be cognizant of the ER Pollution Prevention and Waste Minimization Awareness program. Currently, the ability of the ER Waste Minimization and Pollution Prevention Awareness Program to succeed is closely tied to the participation of the project manager. An ER pollution prevention awareness initiative that includes training, involvement, and incentives should be directed at project managers.

In addition, an analysis of the roles and responsibilities assumed by the individuals designated as Waste Reduction Coordinators is necessary to determine where additional resources may be needed. The Waste Reduction Coordinators experience great competition for their time. Following this resource analysis, the specific roles and responsibilities of the Waste Reduction Coordinators may need to be redefined and communicated through discussions of the applicable sections of the ER Plan, as well as through performance indicators in job descriptions.

In order to provide for efficiencies in the Waste Reduction Coordinators activities, the Waste Reduction Coordinators and their site-wide pollution prevention manager, ER pollution prevention manager, and ER Program Manager should communicate and identify areas of shared responsibilities that may be streamlined through standardized reporting. The tracking system outlined in the ER Plan needs to be communicated to the Waste Reduction Coordinators, and their tracking and reporting responsibilities associated with this system need to be defined.

The Waste Reduction Coordinators indicate that ER participation is strong in the site pollution prevention programs with the exception of the site awards program. Management should promote further ER involvement in the site awards programs, while heightening the awareness of the administrators of the awards programs through communication of the characteristics of ER pollution prevention activities.

Within the ER Program, the RA programs are further advanced than the D\&D programs in the institutionalization and implementation of pollution prevention activities. Viewed in terms of location, the ORR programs are more active in pollution prevention than the Paducah and Portsmouth programs. Nonetheless, participation in Oak Ridge needs to increase through the incorporation of the off-site projects and all RA and D\&D projects. As the ER Waste Minimization and Pollution Prevention Awareness Program matures and incorporates an approach to problem solving that allows all personnel to participate in the planning and decision making process, all projects should realize reduced releases of hazardous and toxic materials, and should achieve operating economics and efficiencies. 



\section{REFERENCES}

1. U.S. Department of Energy Program Description for Pollution Prevention, March 1993.

2. Radian Corporation, U.S. Department of Energy Pollution Prevention Awareness Training for K-25 Site Managers, April 1994.

3. Federal Register, Vol. 58, No. 102, p. 31116, May 28, 1993.

4. Radian Corporation, Indexing Cost Avoidance Associated with a Pollution Prevention Option at the Oak Ridge Reservation, June 1994. 
APPENDIX A

QUESTIONNAIRES 
ENVIRONMENTAL RESTORATION PROGRAM WASTE MINIMIZATION SELF-ASSESSMENT

Questionnaire 1

General Site Pollution Prevention Program

1. Who in ER has received the site-wide pollution prevention plans?

2. What ER pollution prevention program objectives are included in the plans?

3. Do the plans describe the pollution prevention program organizational structure?

4. Do the plans describe interaction/coordination between waste generators (ER staff), waste management staff, and other site program staff?

5. Do the plans include organizational responsibilities for pollution prevention?

6. Do the plans include a schedule for furure pollution prevention activities? If so, does the schedule include ER activities?

7. Do the plans include methods for the evaluation of new technologies or the identification of new applications of existing technologies to reduce waste generation?

8. Do the plans describe pollution prevention information and technology exchange activities among the divisions or sites that are planned or underway?

9. Is there a baseline estimate for waste stream generation in the plans that includes ER waste? 
10. Have waste stream reduction goals been established? Are they Qualitative or Quantitative?

11. How are ER pollution prevention activities identified and tracked on a site-wide basis?

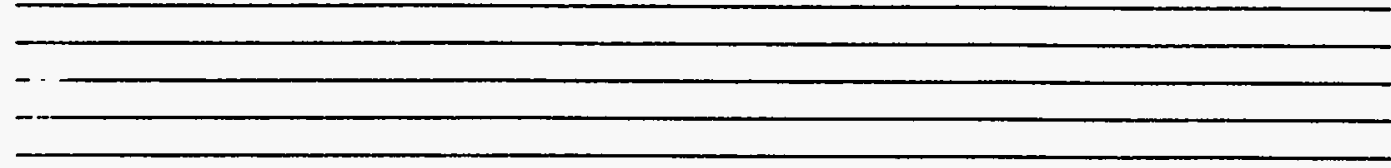

12. What ER pollution prevention activities are coordinated and reported as part of the sites' pollution prevention activities?

13. What has been the Division Pollution Prevention Representative's participation in the sites' pollution prevention council?

14. How does ER participate in pollution prevention awareness activities conducted by the sites?

15. What support does the ER pollution prevention program receive from the sites?

16. How has management communicated their commitment to pollution prevention? 
ENVIRONMENTAL RESTORATION PROGRAM WASTE MINIMIZATION SELF-ASSESSMENT

Questionnaire 2

ER Pollution Prevention Program

1. What plant-level pollution prevention activities do ER personnel participate in (paper and can recycling, affirmative procurement, etc.)?

2. What ER pollution prevention procedures are in place?

3. Who in ER has received the Waste Minimization and Pollution Prevention Awareness Program Plan for DOE-ORO's Environmental Restoration OR-1 Project: FY 1994 - FY 1995 (ES/ER/TM-124)? (List all)

4. Are ER pollution prevention program objectives clearly stated in the plan?

5. Does the plan describe the ER pollution prevention program organizational structure?

6. Does the plan include ER organizational responsibilities for pollution prevention?

7. Does the plan include a schedule for future pollution prevention activities?

8. Does the plan include methods for the evaluation of new technologies or the identification of new applications of existing technologies to reduce waste generation? 
Questionnaire 2

ER Pollution Prevention Program (Continued)

9. Does the plan describe pollution prevention information and technology exchange activities among the sites that are planned or underway?

10. Is there an ER baseline estimate for waste stream generation included in the plan? If so, what is the baseline year?

a. How are the baseline estimates reported in the plan (by waste stream, waste type, waste categories, etc.)?

b. Has an ER waste stream reduction goal been established for each waste stream? Is this included in the plan?

11. How are ER pollution prevention activities identified and tracked?

12. Who is responsible for identifying and tracking ER pollution prevention activities?

13. Is an ER pollution prevention awareness program in place? If so, please describe the major attributes of the program.

14. Is there an accepted methodology for calculating waste reduction and associated cost savings? If so, what is it? 
Questionnaire 2

ER Pollution Prevention Program (Continued)

15. What ER Pollution Prevention Opportunity Assessments (PPOAs) have been conducted this fiscal year?

16. What ER PPOAs are planned for the following fiscal year?

17. What material reuse strategies are utilized?

18. How are waste minimization options generated?

19. What pollution prevention training has occurred this fiscal year?

a. Who received this training?

b. Was any of this training specifically focused on ER activities?

20. Do evaluations of job performance take into consideration the accomplishment of pollution prevention objectives?

21. What is the funding for pollution prevention this fiscal year? 
Questionnaire 2

ER Pollution Prevention Program (Continued)

22. What is the estimated funding for pollution prevention for next fiscal year?

23. What pollution prevention provisions are included in existing contracts with subcontractors?

24. How is the awards program administered?

25. How has management communicated their commitment to pollution prevention?

26. Please list any FY 94 pollution prevention/waste minimization accomplishments.

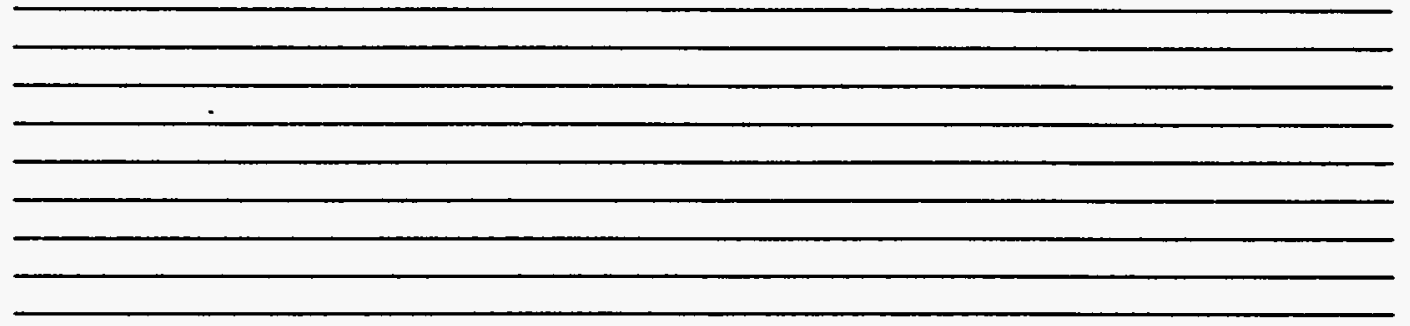

27. How is pollution prevention incorporated into RA and/or D\&D ADS activities?

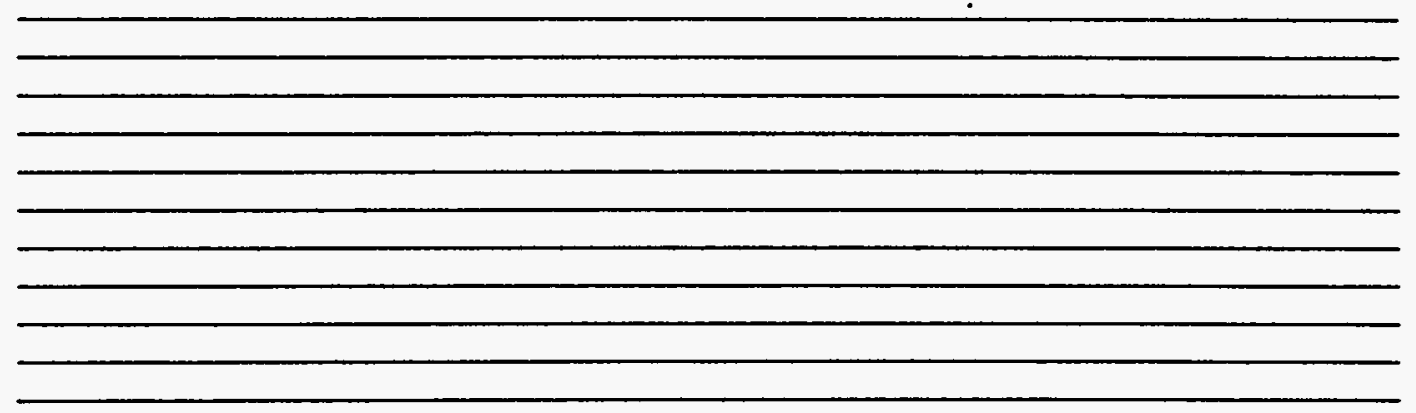


Questionnaire 2

ER Pollution Prevention Program (Continued)

28. How is pollution prevention incorporated into NEPA reviews?

29. What has been the Division Pollution Prevention Representative's participation in the site's pollution prevention council?

30. What are the responsibilities of the Waste Reduction Coordinator?

31. What pollution prevention training has the Waste Reduction Coordinator received this fiscal year?

32. How much time (\%) does the Waste Reduction Coordinator spend on ER pollution prevention activities?

33. What other duties does the Waste Reduction Coordinator have?

34. How are design principles that minimize waste generation incorporated into new construction and into options that involve new or modified processes as required by DOE Order 6430.1A, General Design Criteria? 
APPENDIX B

ANNUAL COST AVOIDANCE 

Worksheet 4

\section{Y-12 D\&D PPE Reduction Project POLLUTION PREVENTION PROJECT SUMMARY COVER SHEET}

\section{DESCRIPTION OF THE POLLUTION PREVENTION OPTION}

Objective: (Discuss the contribution that the pollution prevention option makes toward achieving established program goals for the shop and/or the facility.)

The rescheduling of work hours and breaks for the enhanced S\&M project at Y-12's building $9201-4$. upper floor has reduced the number change outs from $4 /$ day to $2 / \mathrm{day}$. The net effect of reducing the number of change outs is the use of disposable personal protective equipment has been reduced by approximately $50 \%$. The decreases the costs of purchasing new PPE and of disposing of the used and potentially contaminated PPE.

Description of the Current Process: (Discuss the process raw materials used, the process equipment used and maintenance cycles, waste streams generated, pollution controls used, and annual process costs as listed in Worksheet 1.)

The current grocess involves the workers changing out of PPE twice in the morning and twice in the afternoon. The used and potentially contaminated PPE is collected, placed in waste bags and stored for disposal as low level radiological waste. A health physics technician monitors the employees for heat stress.

Description of the Pollution Prevention Option and New Process: (Compare the option with the current process, focusing on the process areas and equipment changed, the waste streams reduced/eliminated, and the annual costs incurred as listed on Worksheet 1. If new equipment will be required, explain. Include discussion of implementation costs presented in Worksheet 2.)

The pollution prevention and new process involves the workers beginning a little later in the morning and working until Junch, thus only changing out once in the morning. All breaks are consolidated during the lunch hour. The workers also work a little longer in the afternoons, also requiring only one change out at the end of the day. The workers are monitored for heat stress to ensure that the longer work periods do not affect their health. If the heat stress becomes unsafe, the workers take a break and change out of their PPE. Under these circumstances, there are additional change outs. and there is no reduction in PPE use or disposal from current practices.

Benefits of the Pollution Prevention Option: (Use Worksheets 1 and 3 to discuss the economic benefits of the option. Discuss other benefits such as reducing/eliminating waste streams, reducing/eliminating toxic materials use, improving process health/safety and community relations, etc.)

The main benefit of the pollution prevention option is the cost savings. The amount of PPE used has been reduced by approximately $50 \%$. This has also reduced generation of used PPE and the associated disposal costs. including waste bags. The only drawback is that workers have to work longer periods of time between breaks. which may increase the potential for heat stress.

Additional Information and Methods Used to Determine the One-Time Implementation Cost and the Index of Annual Cost Avoidance: (Provide specific calculations for determining the category costs listed on Worksheets 1 and 2.)

The only one-time implementation costs associated with the new process is the development of a new work procedure explaining the new work schedule and continued monitoring for heat stress. In conjunction with this new procedure is training for 21 workers for 1 hour. 
Worksheet 1

\section{INDEX OF ANNUAL COST AVOIDANCE}

\begin{tabular}{|c|c|c|}
\hline Category & $\begin{array}{l}\text { Index of } 7 \text { Month Cost } \\
\text { for the Current Process } \\
(\$)\end{array}$ & $\begin{array}{l}\text { Index of } 7 \text { Month Cost } \\
\text { for the New Process (\$) }\end{array}$ \\
\hline $\begin{array}{l}\text { 1A. } 7 \text { MONTH RAW MATERIAL } \\
\text { PURCHASING COSTS }\end{array}$ & & \\
\hline None & & \\
\hline & & \\
\hline & & \\
\hline & & \\
\hline & & \\
\hline & & \\
\hline & & \\
\hline Subtotal (1A) & 0 & 0 \\
\hline $\begin{array}{l}\text { 1B. } 7 \text { MONTH PROCESS } \\
\text { OPERATION COSTS }\end{array}$ & & \\
\hline 1. Utility Costs (use Tables $1 \& 2$ ) & 0 & 0 \\
\hline 2. Process Operation Labor Costs & no change & no change \\
\hline $\begin{array}{l}\text { 3. Routine Maintenance Costs for } \\
\text { Processes }\end{array}$ & 0 & 0 \\
\hline Subtotal (1B) & 0 & 0 \\
\hline \multicolumn{3}{|l|}{$\begin{array}{l}\text { 1C. } 7 \text { MONTH PPE AND RELATED } \\
\text { HEALTH/SAFETY SUPPLY } \\
\text { COSTS }\end{array}$} \\
\hline Subtotal (1C) & $\$ 260,000$ & $\$ 130,322$ \\
\hline
\end{tabular}


Worksheet 1

INDEX OF ANNUAL COST AVOIDANCE (continued)

\begin{tabular}{|c|c|c|}
\hline Category & $\begin{array}{l}\text { Index of 7-Month Cost } \\
\text { for the Current Process } \\
\text { (\$) }\end{array}$ & $\begin{array}{l}\text { Index of } 7 \text { Month Cost } \\
\text { for the New Process (\$) }\end{array}$ \\
\hline \multicolumn{3}{|l|}{$\begin{array}{l}\text { 1D. } 7 \text { MONTH WASTE } \\
\text { MANAGEMENT COSTS }\end{array}$} \\
\hline $\begin{array}{l}\text { 1. Waste Container Costs (use } \\
\text { Table 3) }\end{array}$ & $\$ 601.81$ & $\$ 300.58$ \\
\hline $\begin{array}{l}\text { 2. Treatment/Storage/Disposal } \\
\text { Costs (see Table 4) }\end{array}$ & $\$ 10,747.40$ & $\$ 5,373.70$ \\
\hline 3. Inspection/Compliance Costs & no change & no change \\
\hline Subtotal (1D) & $\$ 11,349.21$ & $\$ 5,674.28$ \\
\hline \multicolumn{3}{|l|}{ 1E. 7 MONTH RECYCLING COSTS } \\
\hline $\begin{array}{l}\text { 1. Material Collection, Separation, } \\
\text { and Preparation Costs }\end{array}$ & 0 & 0 \\
\hline a. Material and Supply Costs & 0 & 0 \\
\hline $\begin{array}{l}\text { Operations and } \\
\text { Maintenance Labor Costs }\end{array}$ & $\mathbf{0}$ & 0 \\
\hline 2. Vendor Cost for Recycling & $\mathbf{0}$ & 0 \\
\hline Subtotal (IE) & $\mathbf{0}$ & 0 \\
\hline $\begin{array}{l}\text { 1F. TOTAL INDEX OF } 7 \text { MONTH } \\
\operatorname{cosT}(1 \mathrm{~A}+1 \mathrm{~B}+1 \mathrm{C}+1 \mathrm{D}+1 \mathrm{E})\end{array}$ & $\$ 271,349.21$ & $\$ 135,996.28$ \\
\hline $\begin{array}{l}\text { 1G. Index of Annual Cost Avoidance } \\
\text { (Total index of annual cost for } \\
\text { current process - total index of } \\
\text { annual cost for new process) }\end{array}$ & & $\$ 135,352.93$ \\
\hline
\end{tabular}


Worksheet 2

ONE-TIME IMPLEMENTATION COST

\begin{tabular}{|c|c|}
\hline Category & Cost (\$) \\
\hline \multicolumn{2}{|l|}{ 2A. New Equipment Purchases } \\
\hline Item 1. None & $\mathbf{0}$ \\
\hline Item 2. & 0 \\
\hline Item 3. & 0 \\
\hline Subtotal (2A) & 0 \\
\hline \multicolumn{2}{|l|}{ 2B. Parts and Labor for Equipment Installation } \\
\hline Item 1. None & 0 \\
\hline Item 2. & 0 \\
\hline Item 3. & 0 \\
\hline Subtotal (2B) & 0 \\
\hline \multicolumn{2}{|l|}{ 2C. Procedure Development } \\
\hline Subtotal (2C) & $\$ 2,000$ \\
\hline 2D. Training & \\
\hline 1. Materials and Contracted Services & 0 \\
\hline 2. Labor & $\$ 861$ \\
\hline Subtotal (2D) & $\$ 861$ \\
\hline 2E. Total One-Time Implementation Cost $(2 \mathrm{~A}+2 \mathrm{~B}+2 \mathrm{C}+2 \mathrm{D})$ & $\$ 2,861$ \\
\hline
\end{tabular}




\section{INDEX OF ANNUAL COST AVOIDANCE SUMMARY}

\begin{tabular}{|c|c|}
\hline Category & $\begin{array}{l}\text { Index of } 7 \text { Month Cost } \\
\text { Avoidance (\$) }\end{array}$ \\
\hline $\begin{array}{l}\text { 3A. Month Raw Material Purchasing Costs from } \\
\text { Worksheet } 1 \text { (Subtotal } 1 \mathrm{~A} \text { of current process - } \\
\text { Subtotal 1A of new process) }\end{array}$ & 0 \\
\hline $\begin{array}{l}\text { 3B. } 7 \text { Month Process Operation Costs from Worksheet } 1 \\
\text { (Subtotal 1B of current process - Subtotal 1B of } \\
\text { new process) }\end{array}$ & 0 \\
\hline $\begin{array}{l}\text { 3C. } 7 \text { Month PPE and Related Health/Safety Supply } \\
\text { Costs from Worksheet } 1 \text { (Subtotal 1C of current } \\
\text { process - Subtotal 1C of new process) }\end{array}$ & $\$ 129,678.00$ \\
\hline $\begin{array}{l}\text { 3D. } 7 \text { Month Waste Management Costs from Worksheet } \\
1 \text { (Subtotal 1D of current process - Subtotal 1D of } \\
\text { new process) }\end{array}$ & $\$ 5.674 .93$ \\
\hline $\begin{array}{l}\text { 3E. } 7 \text { Month Recycling Costs from Worksheet } 1 \\
\text { (Subtotal IE of current process - Subtotal IE of } \\
\text { new process) }\end{array}$ & 0 \\
\hline $\begin{array}{l}\text { 3F. Index of } 7 \text { Month Cost Avoidance } \\
(3 A+3 B+3 C+3 D+3 E)\end{array}$ & $\$ 135,352.93$ \\
\hline $\begin{array}{l}\text { 3G. Total One-Time Implementation Cost (Worksheet 2, } \\
\text { 2E) }\end{array}$ & $\$ 2,861.00$ \\
\hline 3H. Estimated Payback Period (3G $\div 3 \mathrm{~F})$ & $\begin{array}{r}0.02 \text { 7-month periods }=5 \text { days } \\
=0.01 \text { years }\end{array}$ \\
\hline
\end{tabular}


Worksheet 4

\section{QRNL RA Mobile Decon. Trailer Proiect \\ - POLLUTION PREVENTION PROJECT SUMMARY COVER SHEET}

\section{DESCRIPTION OF THE POLLUTION PREVENTION OPTION}

Objective: (Discuss the contribution that the pollution prevention option makes toward achieving established program goals for the shop and/or the facility.)

The recycling/recirculating of water for the decontamination of rad contaminated field equipment during ORNL RA activities contributes to pollution prevention by reducing the amount of decon water that becomes contaminated and requires treatment. Reducing the amount of contaminated decon water also reduced the amount of waste containers required. In addition, by using the mobile decon trailer, decontamination activities are more efficient and require less labor.

Description of the Current Process: (Discuss the process raw materials used, the process equipment used and maintenance cycles, waste streams generated, pollution controls used, and annual process costs as listed in Worksheet 1.)

The current process involves decontaminating field equipment using a large basin with water and soap and scrubbing the loose contamination off with brushes. This results in contaminated waste water. contaminated residue, and PPE waste.

Description of the Pollution Prevention Option and New Process: (Compare the option with the current process, focusing on the process areas and equipment changed, the waste streams reduced/eliminated, and the annual costs incurred as listed on Worksheet 1 . If new equipment will be required, explain. Include discussion of implementation costs presented in Worksheet 2.)

The pollution prevention and new process involves a specially designed mobile decon trailer where the equipment is abrasive blasted with a mix of aluminum garnet and water. The abrasive and water are recirculated/recycled until they become too dirty for further use. The trailer is equipped with compressed air for high pressure abrasive blasting, a spray booth, and supplied air for the worker conducting the abrasive blasting. The new process removes loose contamination more completely and is less labor intensive.

Benefits of the Pollution Prevention Option: (Use Worksheets 1 and 3 to discuss the economic benefits of the option. Discuss other benefits such as reducing/eliminating waste streams, reducing/eliminating toxic materials use, improving process health/safety and community relations, etc.)

The main benefit of the pollution prevention option is the reduction of waste contaminated decon water that requires treatment. The new process also reduces the amount of waste containers required and is less labor intensive. These reductions all result in cost savings.

Additional Information and Methods Used to Determine the One-Time Implementation Cost and the Index of Annual Cost Avoidance: (Provide specific calculations for determining the category costs listed on Worksheets 1 and 2.)

The only one-time implementation costs associated with the new process is the trailer itself which costs_approximately $\$ 175,000$. Most of the trailer is standard design used at nuclear power plants. however, because it is mobile, compressed air for high pressure blasting and supplied air had to be added. 
Worksheet 1

INDEX OF ANNUAL COST AVODANCE

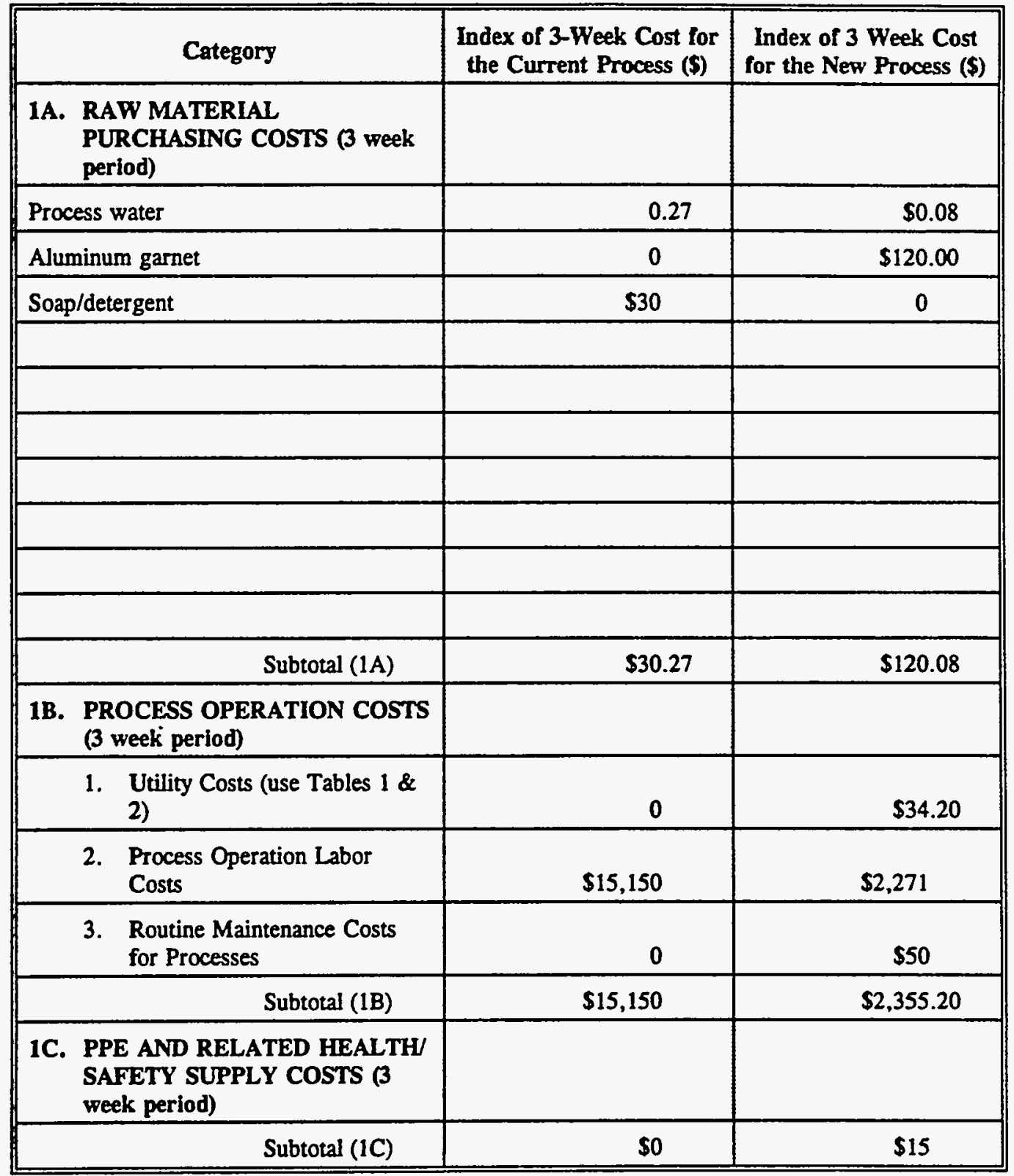


Worksheet 1

INDEX OF ANNUAL COST AVOIDANCE (continued)

\begin{tabular}{|c|c|c|c|}
\hline & Category & $\begin{array}{l}\text { Index of } 3 \text { Week Cost for } \\
\text { the Current Process }(\$)\end{array}$ & $\begin{array}{l}\text { Index of } 3 \text { Week Cost } \\
\text { for the New Process (\$) }\end{array}$ \\
\hline \multicolumn{4}{|c|}{$\begin{array}{l}\text { 1D. WASTE MANAGEMENT } \\
\text { COSTS ( } 3 \text { week period) }\end{array}$} \\
\hline & $\begin{array}{l}\text { 1. Waste Container Costs (use } \\
\text { Table 3) }\end{array}$ & $\$ 357$ & $\$ 71$ \\
\hline & $\begin{array}{l}\text { 2. Treatment/Storage/Disposal } \\
\text { Costs (see Table 4) }\end{array}$ & $\$ 4.103$ & $\$ 328$ \\
\hline & 3. Inspection/Compliance Costs & no change & no change \\
\hline & Subtotal (1D) & $\$ 4,460$ & $\$ 399$ \\
\hline \multicolumn{4}{|c|}{$\begin{array}{l}\text { 1E. RECYCLING COSTS (3 week } \\
\text { period) }\end{array}$} \\
\hline & $\begin{array}{l}\text { 1. Material Collection, } \\
\text { Separation, and Preparation } \\
\text { Costs }\end{array}$ & 0 & 0 \\
\hline & $\begin{array}{ll}\text { a. } & \begin{array}{l}\text { Material and Supply } \\
\text { Costs }\end{array} \\
\end{array}$ & 0 & $\mathbf{0}$ \\
\hline & $\begin{array}{l}\text { b. Operations and } \\
\text { Maintenance Labor } \\
\text { Costs }\end{array}$ & 0 & 0 \\
\hline & 2. Vendor Cost for Recycling & 0 & 0 \\
\hline & Subtotal (1E) & 0 & 0 \\
\hline 1F. & $\begin{array}{l}\text { TOTAL INDEX OF } 3 \text { WEEK } \\
\text { PERIOD COST }(1 \mathrm{~A}+1 \mathrm{~B}+ \\
1 \mathrm{C}+1 \mathrm{D}+1 \mathrm{E})\end{array}$ & $\$ 19,640.27$ & $\$ 2,889.28$ \\
\hline 1G. & $\begin{array}{l}\text { Index of Cost Avoidance (Total } \\
\text { index of } 3 \text { week period cost for } \\
\text { current process - total index of } \\
3 \text { week cost for new process) }\end{array}$ & & $\$ 16,750.99$ \\
\hline
\end{tabular}


Worksheet 2

ONE-TIME IMPLEMENTATION COST

\begin{tabular}{|c|c|}
\hline Category & Cost (\$) \\
\hline \multicolumn{2}{|l|}{ 2A. New Equipment Purchases } \\
\hline Item 1. Mobile decon trailer & $\$ 160,000$ \\
\hline Item 2. Air compressor and tank & $\$ 6,120$ \\
\hline Item 3. Class D Supplied Air System & $\$ 1,563$ \\
\hline Subtotal (2A) & $\$ 167,693$ \\
\hline 2B. Parts and Labor for Equipment Installation & included in $2 \mathrm{~A}$ \\
\hline Item 1. & $\mathbf{0}$ \\
\hline Item 2. & 0 \\
\hline Item 3. & 0 \\
\hline Subtotal (2B) & 0 \\
\hline \multicolumn{2}{|l|}{ 2C. Procedure Development } \\
\hline Subtotal (2C) & $\$ 6,000$ \\
\hline 2D. Training & \\
\hline 1. Materials and Contracted Services & $\mathbf{0}$ \\
\hline 2. Labor & $\$ 488$ \\
\hline Subtotal (2D) & $\$ 488$ \\
\hline 2E. Total One-Time Implementation Cost $(2 \mathrm{~A}+2 \mathrm{~B}+2 \mathrm{C}+2 \mathrm{D})$ & $\$ 174,181$ \\
\hline
\end{tabular}


INDEX OF ANNUAL COST AVOIDANCE SUMMARY

\begin{tabular}{|c|c|}
\hline Category & $\begin{array}{l}\text { Index of } 3 \text { Week Cost } \\
\text { Avoidance (\$) }\end{array}$ \\
\hline $\begin{array}{l}\text { 3A. Week Period Raw Material Purchasing Costs from } \\
\text { Worksheet } 1 \text { (Subtotal 1A of current process - } \\
\text { Subtotal 1A of new process) }\end{array}$ & $-\$ 89.81$ \\
\hline $\begin{array}{l}\text { 3B. } 3 \text { Week Period Process Operation Costs from } \\
\text { Worksheet } 1 \text { (Subtotal 1B of current process - } \\
\text { Subtotal 1B of new process) }\end{array}$ & $\$ 12,794.80$ \\
\hline $\begin{array}{l}\text { 3C. } 3 \text { Week Period PPE and Related Health/Safety } \\
\text { Supply Costs from Worksheet } 1 \text { (Subtotal 1C of } \\
\text { current process - Subtotal 1C of new process) }\end{array}$ & $-\$ 15.00$ \\
\hline $\begin{array}{l}\text { 3D. Week Period Waste Management Costs from } \\
\text { Worksheet } 1 \text { (Subtotal 1D of current process - } \\
\text { Subtotal 1D of new process) }\end{array}$ & $\$ 4,061.00$ \\
\hline $\begin{array}{l}\text { 3E. Week Period Recycling Costs from Worksheet } 1 \\
\text { (Subtotal IE of current process - Subtotal 1E of } \\
\text { new process) }\end{array}$ & 0 \\
\hline $\begin{array}{l}\text { 3F. Index of } 3 \text { Week Period Cost Avoidance } \\
(3 A+3 B+3 C+3 D+3 E)\end{array}$ & $\$ 16,750.99$ \\
\hline $\begin{array}{l}\text { 3G. Total One-Time Implementation Cost Worksheet } 2 \text {, } \\
\text { 2E) }\end{array}$ & $\$ 174,181.00$ \\
\hline 3H. Estimated Payback Period (3G $\div 3 \mathrm{~F})$ & $\begin{array}{r}10.4 \text { (3 week periods) }= \\
0.6 \text { years }\end{array}$ \\
\hline
\end{tabular}


Assumptions:

1) A 3 week period was assumed for costing although decon. activities vary widely and may be sporadic. The time period was based on an average period between change out of decon water. This change out period is directly related to how dirty/contaminated the decon. water becomes, which is dependant on how often decon. activities are carried out and what type of field equipment is being decontaminated. As such, the payback period is very dependant on frequency of use and type of equipment deconed.

2) The wash basin decon. method requires 4 workers and 1 health physics technician 2 hours to complete for a standard set of field equipment. The trailer decon. process required 2 workers and 1 health physics technician 1 hour to complete for a standard set of field equipment.

3) The disposable PPE is the same for each process, except the trailer requires supplied air which generates a waste cartridge filter.

4) All decon. water and residue will be treated as low level waste. 


\section{DISTRIBUTION}

\section{1-2. P. T. Owen}

3. J. V. Spence

4. J. R. Lyons

5-25. W. D. Rideout

26. Central Research Library

27-28. ER Central Document Management Center

29. K-25 Site ER Document Management Center

30. K-25 Site Records 